Article

\title{
The Role of Orientation of Surface Bound Dihydropyrrol-2-ones (DHP) on Biological Activity
}

\author{
Aditi Taunk ${ }^{1}$, Renxun Chen ${ }^{1} \odot$, George Iskander ${ }^{1}$, Kitty K. K. Ho ${ }^{1}$, Basmah Almohaywi ${ }^{1}$, \\ David StClair Black ${ }^{1}$, Mark D. P. Willcox ${ }^{2}$ and Naresh Kumar 1,* \\ 1 School of Chemistry, University of New South Wales, Sydney 2052, Australia \\ 2 School of Optometry and Vision Science, University of New South Wales, Sydney 2052, Australia \\ * Correspondence: n.kumar@unsw.edu.au
}

Academic Editor: Derek J. McPhee

Received: 12 June 2019; Accepted: 10 July 2019; Published: 23 July 2019

\begin{abstract}
Quorum sensing (QS) signaling system is important for bacterial growth, adhesion, and biofilm formation resulting in numerous infectious diseases. Dihydropyrrol-2-ones (DHPs) represent a novel class of antimicrobial agents that inhibit QS, and are less prone to develop bacterial resistance due to their non-growth inhibition mechanism of action which does not cause survival pressure on bacteria. DHPs can prevent bacterial colonization and quorum sensing when covalently bound to substrates. In this study, the role of orientation of DHP compounds was investigated after covalent attachment by 1-ethyl-3-(3-dimethylaminopropyl)carbodiimide (EDC)/N-hydroxysuccinimide (NHS) coupling reaction to amine-functionalized glass surfaces via various positions of the DHP scaffold. The functionalized glass surfaces were characterized by X-ray photoelectron spectroscopy (XPS) and contact angle measurements and tested for their in vitro biological activity against $S$. aureus and P. aeruginosa. DHPs attached via the $\mathrm{N}-1$ position resulted in the highest antibacterial activities against S. aureus, while no difference was observed for DHPs attached either via the N-1 position or the C-4 phenyl ring against $P$. aeruginosa.
\end{abstract}

Keywords: quorum sensing; surface attachment; Pseudomonas; Staphylococcus; antimicrobial; biomaterials

\section{Introduction}

According to the World Health Organization (WHO), infectious diseases are the second leading cause of death and are responsible for approximately 15 million deaths every year worldwide [1]. Bacteria are responsible for about $90 \%$ of all infections [2]. According to estimates from the USA Centers for Disease Control and Prevention, almost 2 million people are infected with bacteria that are resistant to antibiotics, and at least 23,000 people die as a direct result of these infections each year in the USA [3]. Also, recent reports suggest that by 2050 drug-resistant infections will be the leading cause of deaths in the world with the death rate going up to 10 million each year $[4,5]$.

The insertion of indwelling or implanted foreign polymer bodies such as cardiovascular devices [6], dental [7,8], orthopaedic [9], cochlear implants [10,11], catheters [12-14], contact lenses [15], and many more have become an indispensable part of modern medical care. Many are life saving devices that are responsible for significantly improving the quality of life and also increasing the life expectancy of patients [16]. However, the insertion or implantation of medical devices has been associated with a risk of microbial infections $[17,18]$.

A promising strategy to prevent infections of biomedical devices is to coat the material's surface with a suitable antibacterial agent. Compared to conventional antibiotics, quorum sensing (QS) inhibitors such as dihydropyrrolones (DHPs) are excellent coating agents for medical implants since they are potentially less liable to induce the development of antibacterial resistance and have broad spectrum antibacterial activity with low cytotoxicity [19-23]. 
The surface concentration of covalently-attached DHPs can have a large impact on the activity of coated surfaces, with higher amounts of specifically-bound DHPs leading to increased biofilm inhibition [22]. However, it was observed in a previous study that the activity of modified surfaces was not greatly affected by the concentration of DHPs which were grafted by non-specific attachment [24]. These surfaces were equally effective in preventing bacterial colonization at low concentrations against two common pathogens, Staphylococcus aureus and Pseudomonas aeruginosa. This difference in the efficacy of DHPs could be due to changes in the orientation of DHP when immobilized on the surface via non-specific attachment strategy, randomly exposing the more active part of molecule to the bacteria.

For the development of efficient and long-lasting antibacterial devices and implants, it is important to understand the effect of the orientation of the attached active molecule on its activity. To date, no systematic study has been carried out to investigate the effect of different orientations of DHP on antibacterial activity. In the current study, potent DHP compounds that have been reported in previous studies were covalently linked to amine-functionalized glass surface via various positions on the DHP scaffold by EDC/NHS coupling reaction. The functionalized glass surfaces were characterized by XPS and contact angle measurements and tested for their antimicrobial activity against $S$. aureus and P. aeruginosa.

\section{Results}

\subsection{Synthesis of DHP Analogues}

A series of DHP analogues having a similar structural skeleton were functionalized with a free carboxylic acid group at the N-1 position (Figure 1A) with different substituents at the phenyl C-4 position according to a modification of a method developed by Kumar and Iskander [20]. This generated a site of attachment at the $\mathrm{N}$-atom of the lactam ring with minimal change to the molecular structure of the DHP. Further, a carboxylic acid group was introduced at the para position of C-4 phenyl ring of DHP to provide an alternative attachment site on the other side of the molecule. (Figure 1B). Previously, para-bromo and fluorine substitutions on the phenyl ring were shown to be potent antimicrobial DHP compounds [25]. Hence, the four acid-functionalized DHP compounds used in this study were chosen with these substitutions on the phenyl ring.

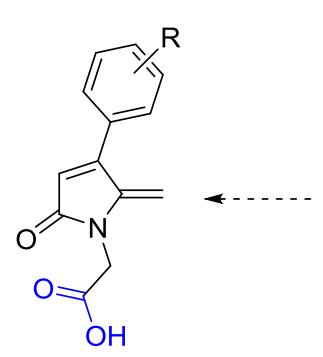

A

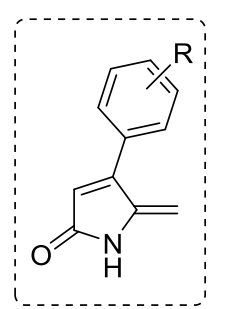

Active compound

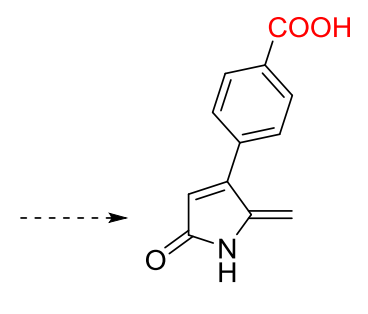

B

Figure 1. Functionalization of active dihydropyrrolones (DHP) with carboxylic acid group at N-1 position (A), and C-4 phenyl ring (B).

The acid-functionalized DHP analogues (DHP acid 1-4) were synthesized via a tert-butyl acetate DHP intermediate which was in turn obtained by reacting various 5-hydroxy-5-methyl-4-aryl-1,5-dihydro-2H-pyrrol-2-ones $\mathbf{1}$ with tert-butyl chloroacetate $\mathbf{2}$ in the presence of potassium hydroxide (Scheme 1). The proton NMR spectra of the intermediates, tert-butyl-2-(5-(2-(tert-butoxy)-2-oxoethoxy)-5-methyl-2-oxo-4-aryl-1,5-dihydro-2H-pyrrol-1-yl)acetate 3 , confirmed the presence of two tert-butyl acetate groups in each compound by the appearance of a singlet at $1.46 \mathrm{ppm}$ for the $\mathrm{CH}_{3}$ groups. In the next step the intermediate compounds were treated with trifluoroacetic acid, which facilitated cleavage of ether at C-5 resulting in removal 
of the ester group followed by dehydration to form the characteristic C- 5 vinylic double bond. At the same time the $\mathrm{N}-1$ ester group underwent hydrolysis in the presence of trifluoroacetic acid to convert it to carboxylic acid. The disappearance of the peaks for the C-5 acetate group and N-1 tert-butyl group in the NMR spectrum indicated completion of the reaction. The crude product was washed with saturated sodium bicarbonate and dried under vacuum to give the pure product of 2-(5-methylene-2-oxo-4-aryl-1,5-dihydro-2H-pyrrol-1-yl)acetic acid 4 (DHP acids 1-4).

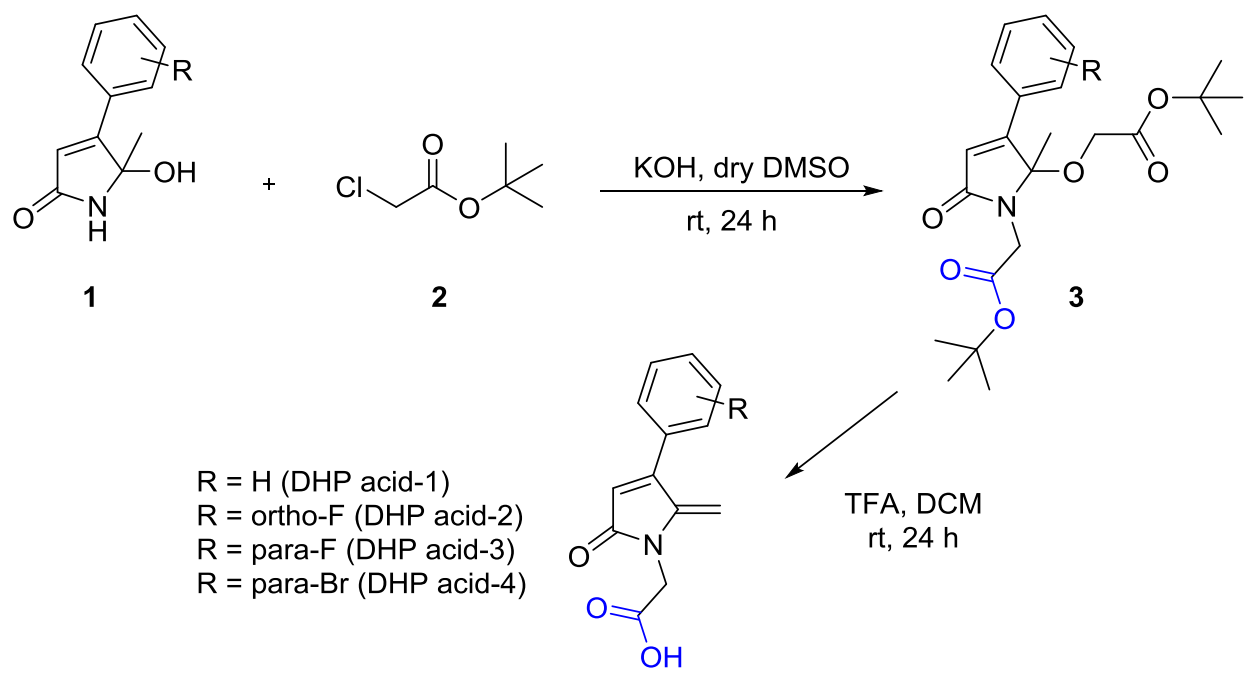

4

Scheme 1. Synthesis of acid derivatives of DHPs (DHP acids 1-4).

The $p$-acid DHP compound was synthesized through a series of steps as shown in Scheme 2. 4-(2-Oxopropyl)benzoic acid 5 was reacted with glyoxylic acid 6 at $75-80^{\circ} \mathrm{C}$ for $5 \mathrm{~h}$ to generate the di-acid compound in $50 \%$ yield after flash column chromatography purification. The identity of the di-acid product, (Z)-4-(1-carboxy-3-oxobut-1-en-2-yl)benzoic acid 7, was confirmed by proton NMR spectroscopy. Cyclization of the di-acid compound to form the corresponding furanone compound 8 with a hydroxyl group at C-5 was accomplished in the next step by using trifluoroacetic acid. The reaction was monitored by TLC which confirmed formation of the hydroxyl furanone after $1 \mathrm{~h}$.<smiles>CC(=O)Cc1ccc(C(=O)O)cc1</smiles>

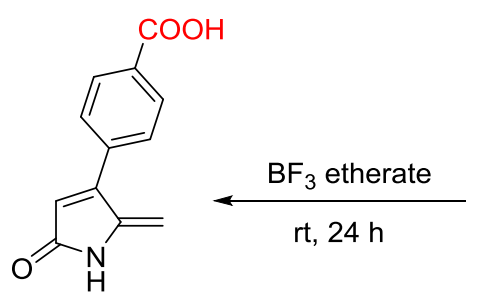

11

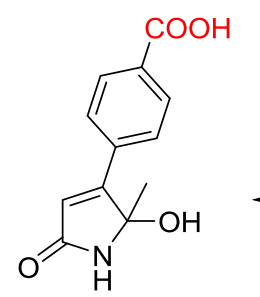

10

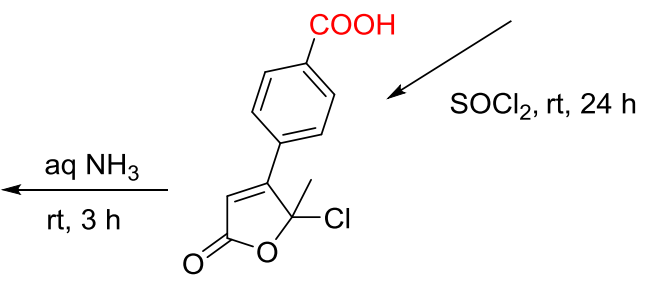

9

Scheme 2. Synthetic route for $p$-acid DHP. 
The next step involved a lactone to lactam ring conversion which was initially attempted by reaction of the hydroxyl furanone with aqueous $\mathrm{NH}_{3}$. However, this was unsuccessful due to the formation of multiple unexpected products. Instead, the C-5 hydroxyl group was replaced with chlorine by using thionyl chloride as the chlorinating agent. To avoid concomitant chlorination of the carboxylic acid group, the reaction was carried out at room temperature. The reaction was continuously monitored by TLC which indicated the reaction was complete after $24 \mathrm{~h}$. The 5-chlorofuranone compound 9 successfully underwent the lactone to lactam conversion with aqueous ammonia giving the desired DHP product, 5-hydroxy-5-methyl-4-(4-carboxyphenyl) -1,5-dihydro-2H-pyrrol-2-one 10, after $3 \mathrm{~h}$. The formation of the DHP product was confirmed by its proton NMR spectrum in DMSO, which exhibited a characteristic broad peak at $8.5 \mathrm{ppm}$ representing the $-\mathrm{NH}$ group of the lactam ring.

The final step involved dehydration of the hydroxyl DHP 10 to regenerate the methylene group at the C-5 position. Dehydration was carried out by using borontrifluoride etherate as the dehydrating agent. The proton NMR analysis of the product showed the presence of two singlet peaks at $5.19 \mathrm{ppm}$ and $6.42 \mathrm{ppm}$ corresponding to the two protons of the C-5 double bond, indicating successful dehydration to form 4-(4-carboxy phenyl)-5-methyelene-1,5-dihydro-2H-pyrrol-2-one 11 ( $p$-acid DHP).

Overall, four DHPs with carboxylic acid groups at the N-1 position of the lactam ring (DHP acids 1-4) and one DHP analogue with a carboxylic group at the C-4 pendant phenyl ring ( $p$-acid DHP) were synthesized (Figure 2).

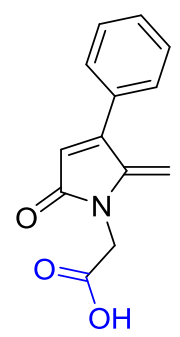

DHP acid-1

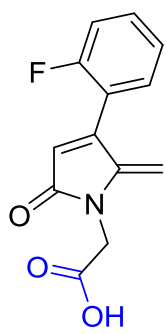

DHP acid-2

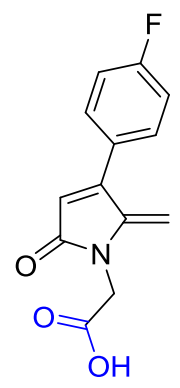

DHP acid-3
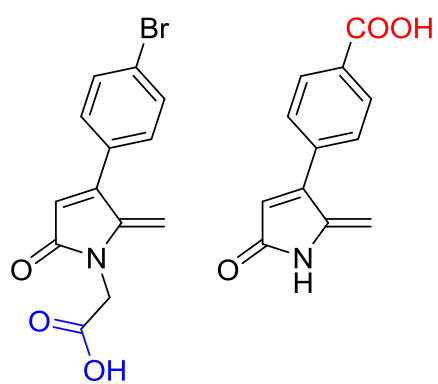

DHP acid-4

p-acid DHP

Figure 2. Chemical structures of DHP derivatives synthesized.

\subsection{Surface Characterization by X-ray Photoelectron Spectroscopy (XPS)}

The resulting acid-DHP derivatives were grafted onto (3-aminopropyl)triethoxysilane (APTES)-functionalized glass substrates by the 1-ethyl-3-(3-dimethylaminopropyl)carbodiimide (EDC)/N-hydroxysuccinimide (NHS) coupling reaction (Scheme 3). XPS elemental analysis was carried out to determine the surface composition after every modification step. The elemental composition of the glass surfaces is shown in Table 1.

The changes in the carbon, nitrogen, and halogen composition on the glass surface before and after attachment of APTES and DHPs indicated successful surface modification (Table 1). The carbon and nitrogen concentration increased drastically from $6.6 \%$ and $0.6 \%$ to $45.4 \%$ and $8.1 \%$, respectively, after functionalization of surface by APTES [24,26]. The subsequent attachment of DHP acids 1-4 and $p$-acid DHP further increased carbon content by $1.8 \%-6.3 \%$ and $4.8 \%$ respectively compared to the APTES control. Similarly, the nitrogen concentration also increased by $0.7 \%-2.7 \%$ after reaction with DHP acids and by $1.1 \%$ for $p$-acid DHP. Furthermore, the halogens detected in the XPS analysis confirmed the attachment of halogenated DHP acids 2-3 on the APTES glass surface. As indicated by the halogen content, the highest attachment efficiency was displayed by DHP acid-4 $(0.91 \% \mathrm{Br})$ which was approximately 2-5 times higher than the fluorine substituted DHPs. This was followed by DHP acid-2 $(0.4 \%$ ortho-F) which had roughly twice the amount of fluorine as DHP acid-3 $(0.17 \%$ para-F). In absence of halogen, the surface coverage of DHP acid-1 and $p$-acid DHP was determined by the 
carbon and nitrogen values which indicate both the non-halogenated DHPs have similar coverage on the APTES glass surface.
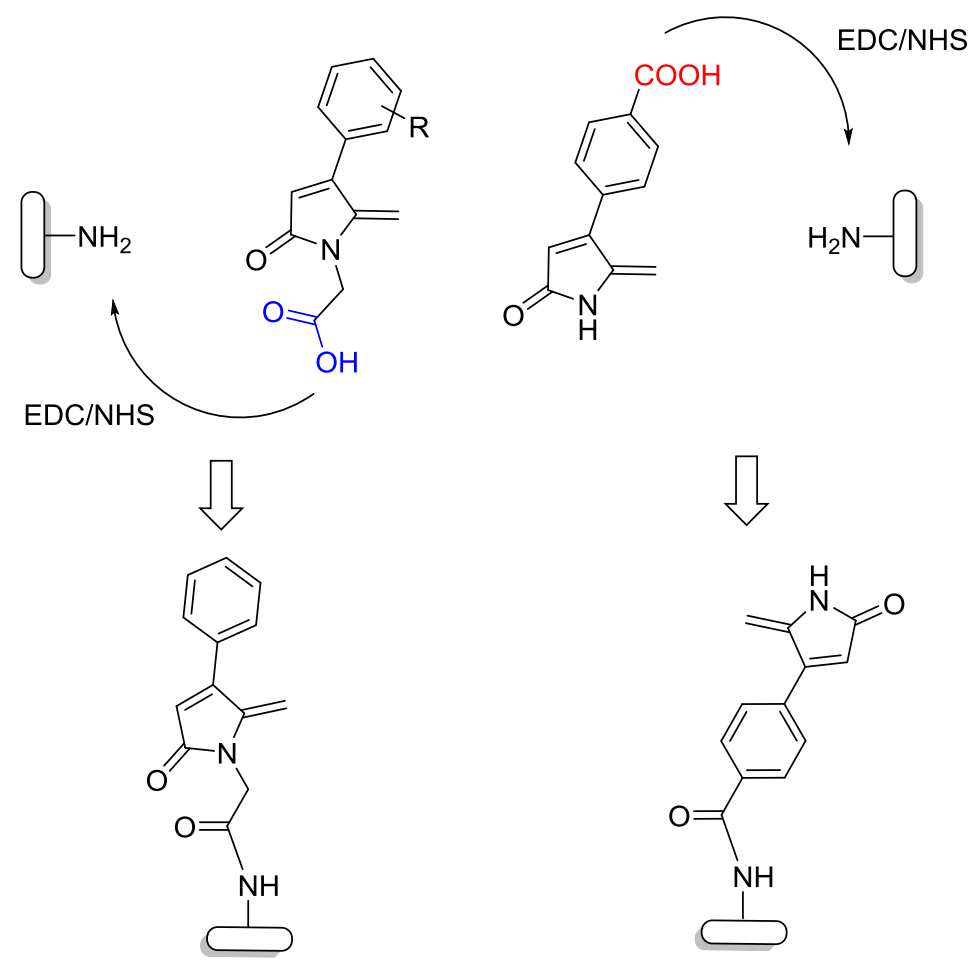

Scheme 3. Specific covalent attachment of DHPs on amine-functionalized surfaces using the 1-ethyl-3-(3-dimethylaminopropyl)carbodiimide (EDC)/N-hydroxysuccinimide (NHS) coupling reaction.

Table 1. XPS elemental composition of blank, (3-Aminopropyl)triethoxysilane (APTES) and DHP-modified glass surfaces.

\begin{tabular}{cccc}
\hline Surface & $\mathbf{\% C}$ & $\mathbf{\% N}$ & $\mathbf{\% H a l o g e n}$ \\
\hline Blank & 6.6 & 0.6 & - \\
APTES & 45.4 & 8.1 & - \\
DHP acid-1 & 48.6 & 8.9 & - \\
DHP acid-2 & 49.3 & 8.8 & $0.40 \% \mathrm{~F}$ \\
DHP acid-3 & 47.2 & 10.8 & $0.17 \% \mathrm{~F}$ \\
DHP acid-4 & 51.7 & 10.3 & $0.91 \% \mathrm{Br}$ \\
p-acid DHP & 50.2 & 9.2 & - \\
\hline
\end{tabular}

The curve fitting results for $\mathrm{C} 1 \mathrm{~s}$ and $\mathrm{N} 1 \mathrm{~s}$ regions and proposed assignments based on chemical shifts are shown in Table 2. The $\mathrm{C} 1 \mathrm{~s}$ spectrum for APTES glass showed three carbon species assigned to an aliphatic carbon at $284.9 \mathrm{eV}, \mathrm{C}-\mathrm{N}$ at $285.9 \mathrm{eV}$ and $\mathrm{C}=\mathrm{O}$ at $287.9 \mathrm{eV}$. For the DHP-treated surfaces, a new peak emerged at $\sim 288.6 \mathrm{eV}$ corresponding to the amide bond $(\mathrm{N}-\mathrm{C}=\mathrm{O})$, indicating successful reaction of DHPs with the APTES surface.

The $\mathrm{N}$ 1s high resolution scan for all the glass samples showed peaks at around $399.5 \mathrm{eV}$ and $401.5 \mathrm{eV}$ which were assigned to an amine bond and $\mathrm{NH}_{3}{ }^{+} /$tertiary nitrogen respectively (Table 2 ). For the DHP glass surfaces, the peak at $\sim 400 \mathrm{eV}$ was attributed to the nitrogen from the amide bond $(\mathrm{N}-\mathrm{C}=\mathrm{O})$, which is an indication of surface modification by the DHP compounds. The ratio of the nitrogen species for all the glass surfaces changed after DHP modification, notably with an increase in peak area for the amide bond. 


\subsection{Contact Angle Measurements}

Static water contact angle measurements were employed to determine the changes in hydrophobicity of the surface which indicates changes in surface chemical composition after every step. The hydrophobicity of materials is a useful parameter that is correlated with cell-biomaterial interfacial interactions $[27,28]$. The contact angle of the uncoated blank glass surface was $19^{\circ}$ (Table 3 ). After modification with APTES, a significant increase in surface hydrophobicity was observed, with a contact angle value of $72^{\circ}$. The contact angle values remained approximately the same $\left(68-75^{\circ}\right)$ after subsequent attachment of DHPs due to the relatively hydrophobic nature of the DHPs.

Table 2. XPS binding energies for C1s and N1s and proposed assignments with percentage peak intensities.

\begin{tabular}{|c|c|c|c|c|c|c|}
\hline \multirow[b]{2}{*}{ Surface } & \multicolumn{3}{|c|}{ C 1s } & \multicolumn{3}{|c|}{ N 1s } \\
\hline & $\begin{array}{c}\text { Binding } \\
\text { energy }(e V)\end{array}$ & Assignment & $\begin{array}{c}\text { Peak area } \\
(\%)\end{array}$ & $\begin{array}{c}\text { Binding } \\
\text { energy }(e V)\end{array}$ & Assignment & $\begin{array}{c}\text { Peak area } \\
(\%)\end{array}$ \\
\hline \multirow{3}{*}{ APTES } & 284.9 & $\mathrm{C}-\mathrm{C}$ & 63.0 & 399.5 & $\mathrm{NH}_{2}$ & 80.2 \\
\hline & 285.9 & $\mathrm{C}-\mathrm{N}$ & 25.5 & 401.4 & $\mathrm{NH}_{3}{ }^{+}$, Tertiary $\mathrm{N}$ & 19.7 \\
\hline & 287.9 & $\mathrm{C}=\mathrm{O}$ & 11.4 & & & \\
\hline \multirow{4}{*}{ DHP acid-1 } & 284.8 & $\mathrm{C}-\mathrm{C}$ & 57.0 & 399.5 & $\mathrm{NH}_{2}$ & 34.0 \\
\hline & 285.8 & $\mathrm{C}-\mathrm{N}$ & 21.0 & 400.2 & $\mathrm{~N}-\mathrm{C}=\mathrm{O}$ & 56.6 \\
\hline & 287.8 & $\mathrm{C}=\mathrm{O}$ & 11.6 & 401.6 & $\mathrm{NH}_{3}{ }^{+}$, Tertiary $\mathrm{N}$ & 9.4 \\
\hline & 288.6 & $\mathrm{~N}-\mathrm{C}=\mathrm{O}$ & 10.4 & & & \\
\hline \multirow{4}{*}{ DHP acid-2 } & 284.8 & $\mathrm{C}-\mathrm{C}$ & 56.7 & 399.5 & $\mathrm{NH}_{2}$ & 30.9 \\
\hline & 285.8 & $\mathrm{C}-\mathrm{N}$ & 21.2 & 400.2 & $\mathrm{~N}-\mathrm{C}=\mathrm{O}$ & 58.3 \\
\hline & 287.8 & $\mathrm{C}=\mathrm{O}$ & 12.1 & 401.6 & $\mathrm{NH}_{3}{ }^{+}$, Tertiary $\mathrm{N}$ & 10.8 \\
\hline & 288.6 & $\mathrm{~N}-\mathrm{C}=\mathrm{O}$ & 10.0 & & & \\
\hline \multirow{4}{*}{ DHP acid-3 } & 284.8 & $\mathrm{C}-\mathrm{C}$ & 55.8 & 399.4 & $\mathrm{NH}_{2}$ & 21.7 \\
\hline & 285.8 & $\mathrm{C}-\mathrm{N}$ & 24.2 & 400.0 & $\mathrm{~N}-\mathrm{C}=\mathrm{O}$ & 67.6 \\
\hline & 287.8 & $\mathrm{C}=\mathrm{O}$ & 10.0 & 401.6 & $\mathrm{NH}_{3}{ }^{+}$, Tertiary $\mathrm{N}$ & 10.7 \\
\hline & 288.7 & $\mathrm{~N}-\mathrm{C}=\mathrm{O}$ & 10.0 & & & \\
\hline \multirow{4}{*}{ DHP acid-4 } & 284.8 & $\mathrm{C}-\mathrm{C}$ & 60.0 & 399.4 & $\mathrm{NH}_{2}$ & 36.8 \\
\hline & 285.8 & $\mathrm{C}-\mathrm{N}$ & 22.8 & 400.0 & $\mathrm{~N}-\mathrm{C}=\mathrm{O}$ & 59.7 \\
\hline & 287.6 & $\mathrm{C}=\mathrm{O}$ & 8.8 & 401.4 & $\mathrm{NH}_{3}{ }^{+}$, Tertiary $\mathrm{N}$ & 3.5 \\
\hline & 288.6 & $\mathrm{~N}-\mathrm{C}=\mathrm{O}$ & 8.4 & & & \\
\hline \multirow{4}{*}{$p$-acid DHP } & 284.8 & $\mathrm{C}-\mathrm{C}$ & 67.2 & 399.6 & $\mathrm{NH}_{2}$ & 61.6 \\
\hline & 285.8 & $\mathrm{C}-\mathrm{N}$ & 12.0 & 400.1 & $\mathrm{~N}-\mathrm{C}=\mathrm{O}$ & 31.3 \\
\hline & 287.9 & $\mathrm{C}=\mathrm{O}$ & 14.1 & 401.5 & $\mathrm{NH}_{3}{ }^{+}$, Tertiary $\mathrm{N}$ & 7.1 \\
\hline & 288.4 & $\mathrm{~N}-\mathrm{C}=\mathrm{O}$ & 6.6 & & & \\
\hline
\end{tabular}

Table 3. Contact angle measurements of glass substrates.

\begin{tabular}{cc}
\hline Surface & Contact Angle $\left({ }^{\circ}\right)(\mathbf{( 1 )}$ \\
\hline Blank & 19 \\
APTES & 72 \\
DHP acid-1 & 71 \\
DHP acid-2 & 73 \\
DHP acid-3 & 74 \\
DHP acid-4 & 75 \\
-acid DHP & 68 \\
\hline
\end{tabular}

\subsection{Antibacterial Activity}

The adhesion of $S$. aureus and P. aeruginosa to the modified surfaces was investigated using fluorescence microscopy by staining the surfaces using the BacLight Live/Dead Bacterial Viability kit. The images were analyzed to determine the relative proportion of live and dead bacteria (stained green or red respectively) on each surface and the results for S. aureus SA38 and P. aeruginosa PA01 are shown in Figures 3 and 4, respectively. 

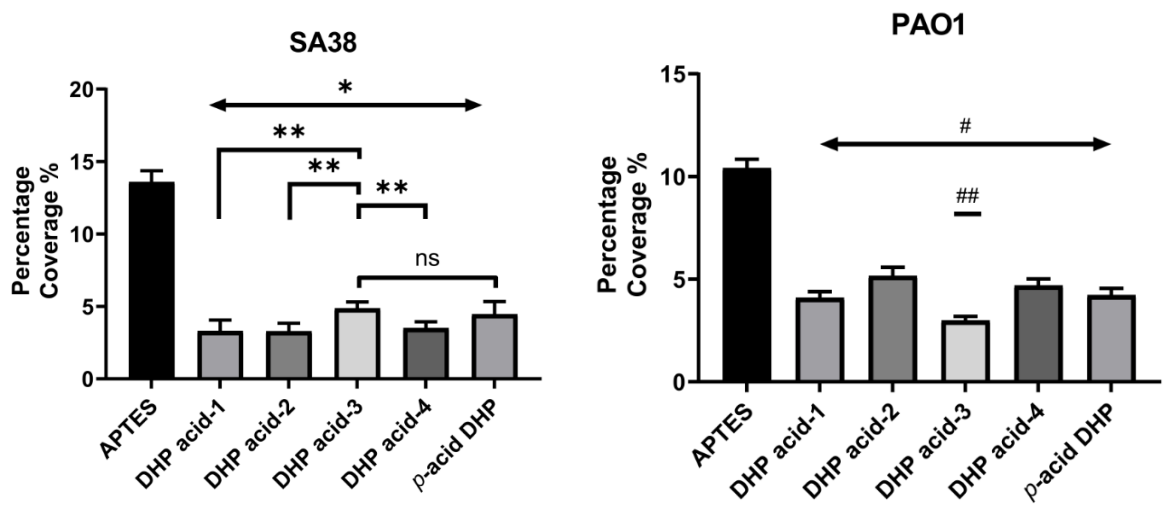

Figure 3. Percentage surface coverage of live and dead bacteria (mean \pm standard deviation of mean) for S. aureus SA38 (Left) and P. aeruginosa PAO1 (Right). For S. aureus SA38: * Indicates $p<0.001$ compared to control; ${ }^{* *}$ indicates $p<0.05$ compared to DHP acid-3 modified glass surfaces. For P. aeruginosa PAO1:

\# Indicates $p<0.001$ compared to control; ${ }^{\# \#}$ indicates $p<0.05$ to all other groups.

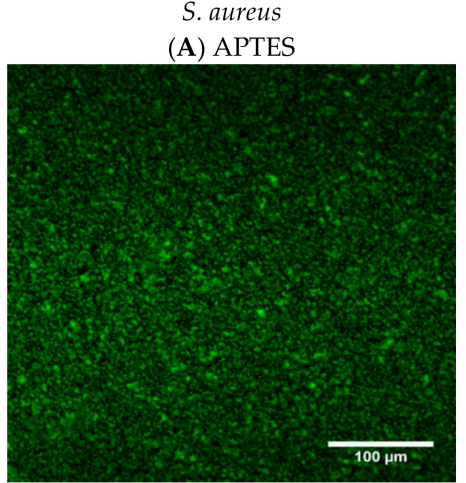

(B) DHP acid-1

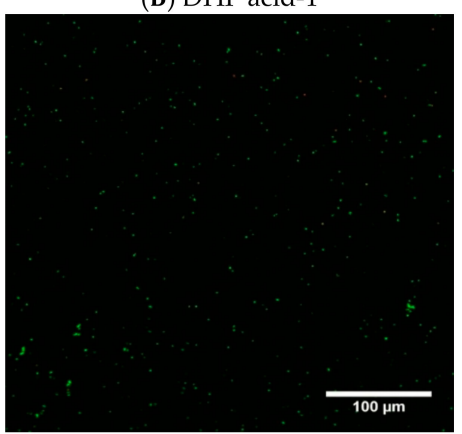

(C) $p$-acid DHP

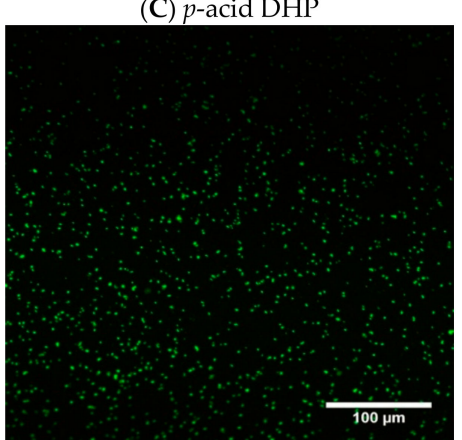

P. aeruginosa

(D)

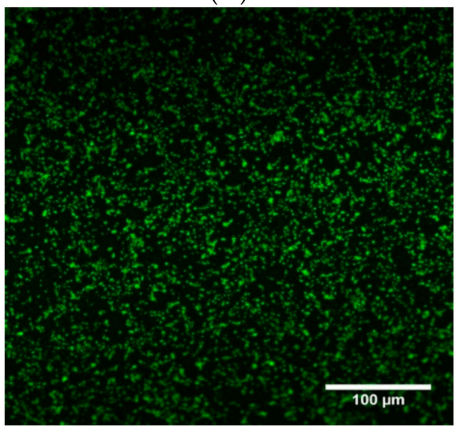

(E)

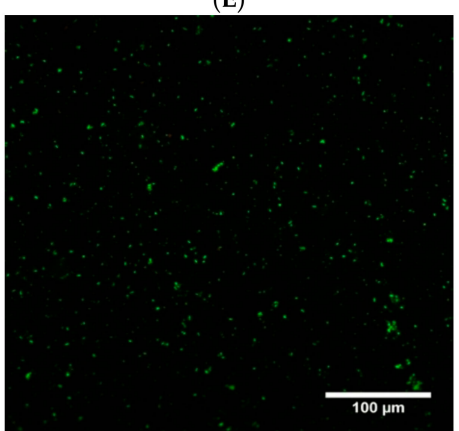

(F)

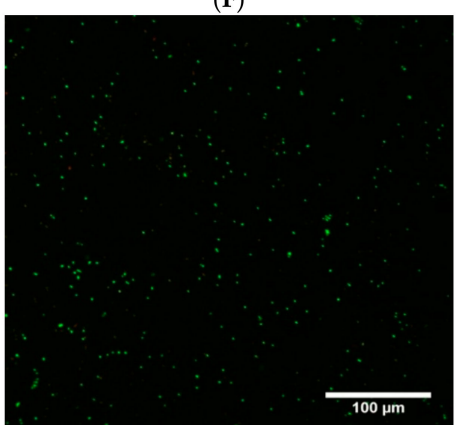

Figure 4. Confocal microscopic images of S. aureus and P. aeruginosa adhered to APTES process control (A,D), DHP acid-1 surfaces (B,E) and $p$-acid DHP surfaces $(\mathbf{C}, \mathbf{F})$. Live bacterial cells stained green and dead bacteria stained red. Magnification 200×. Scale bar $=100 \mu \mathrm{m}$. 
The APTES control surfaces showed extensive colonization of $S$. aureus, with bacterial coverage of more than $13 \%$ (Figure 3). The untreated blank glass surface (data not shown) displayed similar levels of adhesion, suggesting that APTES modification does not have a significant effect on bacterial adhesion. Encouragingly, the DHP-coated glass surfaces displayed significantly lower bacterial coverage compared to the ATPS-coated glass surface. Specifically, the DHP acids 1-4 and p-acid DHP displayed reductions in surface coverage by $64.2 \%-75.8 \%$ and $68.2 \%$ respectively compared to APTES $(p<0.001)$. Among the various DHP acids, surfaces modified with DHP acid-1, DHP acid-2, and DHP acid-4 were the most active against $S$. aureus adhesion and statistically different to DHP acid-3 and $p$-acid DHP $(p<0.05)$. DHP acid-1 $(75.8 \pm 0.8 \%)$, DHP acid-2 $(75.8 \pm 0.5 \%)$, and DHP acid-4 $(74.2 \pm 0.8 \%)$ showed similar efficacies at reducing bacterial coverage, and all three performed better than DHP acid-3 (64.2 $\pm 0.4 \%)$ and $p$-acid DHP which reduced $68.2 \pm 0.4 \%$ of $S$. aureus adhesion.

There was no significant increase in the proportion of dead (red-staining) cells for all modified samples indicating the surfaces inhibit bacterial attachment rather than killing the bacteria (not shown). This may result in a low selective pressure for development of resistance to DHPs $[29,30]$. Representative micrographs of $S$. aureus adhesion on APTES, DHP acid-1, $p$-acid DHP, surfaces are shown in Figure 4.

The image analysis results for P. aeruginosa showed high bacterial coverage on APTES control surfaces ( $>10 \%$; Figure 3 ) and blank glass surfaces (data not shown). Significant reductions in adherent bacterial cells was observed for all the DHP-modified glass surfaces compared to the APTES control (50.4\%-71.3\% reduction for DHP acids $1-4$ and $60.1 \%$ for $p$-acid DHP; $p<0.001)$. DHP acid-3 $(71.3 \pm 0.2 \%)$ showed the highest bacterial reduction compared to the other DHP acids $(p<0.05)$. There were no significant differences between the DHP acid- 1 and $p$-acid DHP $(60.1 \pm 0.3 \%)$ modified glass samples. Similar to $S$. aureus, the percentage of dead P. aeruginosa (red-staining cells) did not increase for any of the modified samples (not shown). Representative micrographs of P. aeruginosa adhesion on APTES, DHP acid-1, and $p$-acid DHP are shown in Figure 4D-F.

\subsection{Quorum Sensing Inhibition Assay}

The QS inhibitory activity of the free DHP compounds was determined using P. aeruginosa MH602 lasB reporter strain ( $\left.\mathrm{P}_{\text {las } B}: g f p(\mathrm{ASV})\right)$ by following the protocol developed by Hentzer et al. [31]. The QS monitor strain carries a plasmid containing a green fluorescent protein (GFP) reporter gene ( $g f p($ ASV) $)$ [32] fused to the promoter of the QS-regulated lasB gene from P. aeruginosa, which causes the bacteria to produce GFP in response to QS signaling. In cell and molecular biology, the GFP gene is frequently used as a reporter of gene expression [33,34]. The short half-life of GFP (ASV) allows for repeated measurements of the same cells to continually assess gene activity over a period of time [35]. The level of GFP expression thus reflects the level of QS in the bacterial culture, and compounds that inhibit QS should result in a lowered expression of GFP. The results of the QS inhibition assay of the DHP compounds are presented in Table 4.

Table 4. QS inhibition activity (\%) against P. aeruginosa MH602 lasB reporter strain at different concentrations of DHP derivatives; ${ }^{a}$ growth inhibition $\leq 10 \%$; ${ }^{b}$ growth inhibition $11 \%-30 \%$; growth inhibition $>30 \%$.

\begin{tabular}{cccc}
\hline \multirow{2}{*}{ Compound } & \multicolumn{3}{c}{ QS Inhibition against PA MH602 (\%) } \\
\cline { 2 - 4 } & $\mathbf{6 2 . 5} \boldsymbol{\mu \mathbf { M }}$ & $\mathbf{1 2 5} \boldsymbol{\mu \mathbf { M }}$ & $\mathbf{2 5 0} \boldsymbol{\mu M}$ \\
\hline DHP acid-1 & $27.6 \pm 1.7^{\mathrm{a}}$ & $40.4 \pm 1.2^{\mathrm{a}}$ & $56.3 \pm 0.4^{\mathrm{b}}$ \\
DHP acid-2 & $33.5 \pm 1.2^{\mathrm{a}}$ & $34.2 \pm 2.3^{\mathrm{a}}$ & $55.3 \pm 3.8^{\mathrm{a}}$ \\
DHP acid-3 & $33.0 \pm 1.8^{\mathrm{a}}$ & $35.2 \pm 2.0^{\mathrm{a}}$ & $57.5 \pm 0.7^{\mathrm{b}}$ \\
DHP acid-4 & $31.0 \pm 1.7^{\mathrm{a}}$ & $35.1 \pm 1.1^{\mathrm{a}}$ & $53.6 \pm 1.5^{\mathrm{a}}$ \\
p-acid DHP & $35.0 \pm 2.4^{\mathrm{a}}$ & $38.5 \pm 1.1^{\mathrm{b}}$ & $68.6 \pm 1.1^{\mathrm{b}}$ \\
Furanone-30 (positive control) & $41.4 \pm 2.7^{\mathrm{a}}$ & $64.2 \pm 3.5^{\mathrm{b}}$ & $89.7 \pm 4.6^{\mathrm{c}}$ \\
\hline
\end{tabular}


The $p$-acid DHP showed highest inhibition of $68.6 \%$ at $250 \mu \mathrm{M}$ followed by DHP acid-3 and DHP acid- 1 which showed $57.5 \%$ and $56.3 \%$ inhibition. At $125 \mu \mathrm{M}$ concentration DHP acid- 1 (40.4\%) and p-acid DHP (38.5\%) had maximum QS inhibition while the remaining DHPs displayed similar level of inhibition. The inhibition values did not vary significantly for halogenated DHPs (DHP acid 2-4) at all concentrations $(62.5-250 \mu \mathrm{M})$. Overall, $p$-acid DHP and DHP acid-3 displayed maximum inhibition.

\section{Discussion}

In the current study, the antibacterial efficacy of DHPs attached from two points on the molecule to glass surfaces was investigated. The DHP were successfully functionalized to yield DHP acids 1-4 and p-acid DHP. The XPS analysis of the coatings demonstrated that DHPs were successfully incorporated onto the APTES-glass surfaces via either the C-4 phenyl ring (DHP acids 1-4) or the $\mathrm{N}$-atom of the DHP (p-acid DHP). Analysis of the halogen content indicated that DHP acid-4 had the highest attachment efficiency, followed by two fluorinated DHP acid-2 and DHP acid-3. The DHP surface coatings were tested for their ability to reduce the adherent bacterial cells of S. aureus and P. aeruginosa, while the free DHPs were also tested for their QS inhibitory activity.

All DHP coatings were shown to reduce S. aureus and P. aeruginosa adhesion to the surface. For P. aeruginosa the orientation of the DHP does not seem to affect the activity, with all surfaces, except DHP acid 3, having similar activities. This is unexpected as in solution, the lactam ring of the DHP is known to be the more potent part of the molecule for QS inhibition than the phenyl group. This was further confirmed using the QS inhibitory activity assay, which showed that $p$-acid DHP compound (68.6\% QS inhibition at $250 \mu \mathrm{M}$ ) which is unmodified at the N1-atom, was more active against $P$. aeruginosa MH602 QS than DHP acid 1-4 ( $<57.5 \%)$. However, this QS inhibitory effects could possibly be negated when the $p$-acid DHP is constricted when bound, as shown by our results that no general trend in the P. aeruginosa activity could be established between $p$-acid DHP and DHP acid 1-4.

Despite this, surfaces with DHP acid-3 with a para-fluoro on the phenyl ring showed the lowest P. aeruginosa adhesion, while the surfaces with a related ortho-fluoro DHP (DHP acid-2) had significantly higher adhesion in comparison. These results were consistent with a previous study by Ho et al. where analogues of DHPs were functionalized with an acrylate group at the N-1 position and grafted onto APTES glass via Michael addition reaction [26]. In that study, the activity of two fluorinated DHP acids was also different, where the para-fluoro DHP (DHP acid-3) exhibited higher activity even at low surface concentration against P. aeruginosa compared to ortho-fluoro compound (DHP acid-2).

For S. aureus activity, it was found that attachment via N-atom of the DHP resulted in lower adhesion, with 3 out of 4 surfaces (DHP acid-1, DHP acid-2, and DHP acid-4) having improved activity when compared to $p$-acid DHP attached via the $\mathrm{C} 4$ phenyl ring. In comparison, a previous study where the DHPs attached non-specifically via azide chemistry exhibited higher reduction in bacterial adhesion at a lower surface concentration. For instance, the para-bromo DHP compound exhibited low surface attachment $(0.35 \% \mathrm{Br}, \mathrm{XPS})$ on the azide surface but displayed bacterial reduction of $93.4 \%$ against $S$. aureus [24], compared to the specific attachment of the same para-bromo DHP (DHP acid-4) in this study, which had nearly three-fold higher surface attachment $(0.91 \% \mathrm{Br}$, XPS) but exhibited only $74.2 \%$ reduction of $S$. aureus adhesion. This indicates that the choice of attachment methodology used, which affects not only the orientation but also concentration of the DHP on the surface, could have a significant influence on antibacterial efficacy.

The surface attached DHPs could act via different pathways for Gram-positive and Gram-negative bacteria. In our previous studies, DHP-coated substrates were shown to be able to disrupt the QS of $P$. aeruginosa by interference with the $N$-acylhomoserine lactones (AHL)-mediated las QS system [22]. It is possible that surface attached DHPs interact with membrane-associated receptor proteins of bacterial cells, preventing the binding of native signal and ultimately resulting in inhibition of expression of the virulence gene lasB. The current study also supports the hypothesis that surface-coated DHP interacts with membranes of bacterial cells, causing a further cascade of events, possibly including dissipation of the bacterial membrane potential that leads to reduction in cell division [36]. In addition, 
for S. aureus, exposure to AHLs have been shown to interfere with the S. aureus agr QS system through interaction with a specific saturable receptor on the cytoplasmic membrane. Furthermore, a derivative of AHL, 3-(1-hydroxydecylidene)-5-(2-hydroxyethyl)pyrrolidine-2,4-dione, has been shown to dissipate both the membrane potential and the $\mathrm{pH}$ gradient of Gram-positive bacteria including Bacillus cereus and S. aureus, resulting in cell death [37]. Therefore, interaction of surface attached DHP with S. aureus through at least two membrane-associated mechanisms are possible.

The physiochemical properties of the surface are also known to have a strong influence on the rate and extent of bacterial adhesion [38-40]. Research has shown that bacteria adhere more easily to non-polar surfaces than to hydrophilic substrates [41,42], that is, higher surface hydrophobicity results in higher biofilm development $[43,44]$. After amine functionalization using APTES silanization on blank glass, the hydrophobicity of the surfaces increased drastically. However, the hydrophobic APTES surface showed similar bacterial coverage as the blank glass, in agreement to previous studies $[45,46]$. Meanwhile, adhesion was significantly reduced after DHP attachment, even though the DHP surfaces had similar hydrophilicity $\left(68-75^{\circ}\right.$ water contact angle) to the APTES surface $\left(72^{\circ}\right)$. This result implies that the reduction in bacterial colonization was caused by the DHP compounds rather than the changes in hydrophobicity of the surface.

\section{Materials and Methods}

\subsection{General}

All chemical reagents were purchased from commercial sources (Alfa-Aesar and Sigma Aldrich, Sydney, Australia) and used without further purification. Solvents were sourced from commercial sources and used as obtained. Reactions were performed using oven-dried glassware under an atmosphere of nitrogen and in anhydrous conditions (as required). Room temperature (rt) refers to the ambient temperature $\left(22-24{ }^{\circ} \mathrm{C}\right)$. Yields refer to chromatographically and spectroscopically pure compounds unless otherwise stated. Reactions were monitored by thin layer chromatography (TLC) precoated with Merck silica gel 60 F254 (Sigma Aldrich, Sydney, Australia). Visualization was performed by the quenching of short or long wavelength UV fluorescence or by staining with potassium permanganate or ninhydrin solution. Flash chromatography was carried out using Grace Davison LC60A 6-35 $\mu \mathrm{m}$ silica gel (Discovery Sciences, Epping, Australia). Preparative thin layer chromatography was carried out on $3 \times 200 \times 200 \mathrm{~mm}$ glass plates coated with Merck $60 \mathrm{GF}_{254}$ silica gel. Infrared spectra were recorded using a Cary 630 FTIR spectrophotometer (Agilent Technologies Australia, Mulgrave, Australia). Ultraviolet spectra were measured using a Cary 100 Bio UV-visible spectrophotometer (Agilent Technologies Australia, Mulgrave, Australia) in the designated solvents and data reported as wavelength $(\lambda)$ in $\mathrm{nm}$ and absorption coefficient $(\varepsilon)$ in $\mathrm{cm}^{-1} \mathrm{M}^{-1}$. High resolution mass spectrometry was performed by the Bioanalytical Mass Spectrometry facility, UNSW. Melting points were obtained using Mel-Temp melting point apparatus and are uncorrected. Proton and carbon NMR was recorded in designated solvents using Bruker DPX 300 or a Bruker Avance 400 spectrometer (Bruker Pty Ltd, Preston, Australia) as designated. Chemical shifts $(\delta)$ are quoted in parts per million (ppm), to the nearest $0.01 \mathrm{ppm}$ and internally referenced relative to the solvent nuclei. ${ }^{1} \mathrm{H}-\mathrm{NMR}$ spectral data are reported as follows: [chemical shift in ppm; multiplicity in br, broad; s, singlet; $d$, doublet; $\mathrm{t}$, triplet; q, quartet; quint, quintet; sext, sextet; sept, septet; m, multiplet; or as a combination of these (e.g. dd, dt etc.)]; coupling constant $(J)$ in hertz, integration, proton count, and assignment.

\subsection{Synthesis of DHP Derivatives}

4.2.1. Tert-Butyl-2-(5-(2-(tert-butoxy)-2-oxoethoxy)-5-methyl-2-oxo-4-phenyl-1,5-dihydro-2H-pyrrol-1-yl) acetate $(3, \mathrm{R}=\mathrm{H})$

5-Hydroxy-5-methyl-4-phenyl-1,5-dihydro-2H-pyrrol-2-one (1.0 g, $2.58 \mathrm{mmol})$ was added to a solution of potassium hydroxide $(0.6 \mathrm{~g}, 10.57 \mathrm{mmol})$ in dry DMSO $(5 \mathrm{~mL})$ and the mixture was stirred at room temperature for $20 \mathrm{~min}$. To the solution tert-butyl chloroacetate $(1.6 \mathrm{~g}, 10.57 \mathrm{mmol})$ was added 
and stirred at room temperature for $24 \mathrm{~h}$. The crude mixture was washed with water and extracted into ethyl acetate. The extracted organic layer was dried over sodium sulphate, evaporated under vacuum and flash columned to yield a white solid (1.36 g, 61\%). M.p. $128^{\circ} \mathrm{C} ;{ }^{1} \mathrm{H}-\mathrm{NMR}(300 \mathrm{MHz}$, $\left.\mathrm{CDCl}_{3}\right) \delta 1.46\left(\mathrm{~d}, J=8.6 \mathrm{~Hz}, 21 \mathrm{H}, 7 \times \mathrm{CH}_{3}\right), 4.01\left(\mathrm{~s}, 2 \mathrm{H}, \mathrm{CH}_{2}\right), 4.34\left(\mathrm{~s}, 2 \mathrm{H}, \mathrm{CH}_{2}\right), 6.26(\mathrm{~d}, J=1.2 \mathrm{~Hz}$, $1 \mathrm{H}, \mathrm{CH}), 7.44(\mathrm{~s}, 5 \mathrm{H}, \mathrm{ArH}){ }^{13} \mathrm{C}-\mathrm{NMR}\left(100 \mathrm{MHz}, \mathrm{CDCl}_{3}\right) \delta 23.2\left(\mathrm{CH}_{3}\right), 28.0\left(6 \times \mathrm{CH}_{3}\right), 41.6\left(\mathrm{CH}_{2}\right), 60.9$ $\left(\mathrm{CH}_{2}\right), 82.4(2 \times \mathrm{C}-\mathrm{O}), 96.9(\mathrm{CH}), 121.0(\mathrm{C}), 128.6(2 \times \mathrm{ArCH}), 129.4(\mathrm{ArCH}), 131.9(2 \times \mathrm{ArCH}), 145.1$ (ArC), $150.7(\mathrm{C}), 167.2(\mathrm{C}=\mathrm{O}), 168.9$ (C=O), 172.6 (C=O); IR (ATR): $v_{\max }$ 3071, 2972, 1725, 1703, 1389, 1227, 1150, 1084, 916, 837, 769, $695 \mathrm{~cm}^{-1}$; UV (ACN): $\lambda_{\max } 207 \mathrm{~nm}\left(\varepsilon 8970 \mathrm{~cm}^{-1} \mathrm{M}^{-1}\right), 218$ (9762), 261 $(11,848) ;$ HRMS (ESI) $m / z$ calcd for $\mathrm{C}_{23} \mathrm{H}_{31} \mathrm{NO}_{6} \mathrm{Na} 440.2044[\mathrm{M}+\mathrm{Na}]^{+}$, found 440.2042 .

\subsubsection{2-(5-Methylene-2-oxo-4-phenyl-1,5-dihydro-2H-pyrrol-1-yl)acetic acid (DHP acid-1)}

Trifluoroacetic acid $(2.5 \mathrm{~mL})$ was added to a solution of tert-butyl-2-(2-(2-(tert-butoxy)-2oxoethoxy)-2-methyl-5-oxo-3-phenyl-2,5-dihydro-1H-pyrrol-1-yl) acetate $(1.1 \mathrm{~g}, 2.76 \mathrm{mmol})$ in dichloromethane $(15 \mathrm{~mL})$ and the mixture was stirred at room temperature for $24 \mathrm{~h}$. The reaction mixture was washed with saturated sodium bicarbonate and water. The ethyl acetate layer was separated, dried over sodium sulphate and chromatographed to yield a white solid ( $0.38 \mathrm{~g}, 69 \%)$. M.p. $165-166{ }^{\circ} \mathrm{C} ;{ }^{1} \mathrm{H}-\mathrm{NMR}\left(300 \mathrm{MHz}, \mathrm{CDCl}_{3}\right) \delta 4.52\left(\mathrm{~s}, 2 \mathrm{H}, \mathrm{CH}_{2}\right), 4.98\left(\mathrm{dd}, J=2.7\right.$ and $\left.1.7 \mathrm{~Hz}, 1 \mathrm{H},=\mathrm{CH}_{2}\right)$, $5.08\left(\mathrm{~d}, J=2.7 \mathrm{~Hz}, 1 \mathrm{H},=\mathrm{CH}_{2}\right), 6.30(\mathrm{~s}, 1 \mathrm{H}, \mathrm{CH}), 7.47(\mathrm{~s}, 5 \mathrm{H}, \mathrm{ArH}) ;{ }^{13} \mathrm{C}-\mathrm{NMR}\left(100 \mathrm{MHz}, \mathrm{CDCl}_{3}\right) \delta 40.5$ $\left(\mathrm{CH}_{2}\right), 97.4\left(\mathrm{CH}_{2}\right), 120.8(\mathrm{CH}), 128.6(4 \times \mathrm{ArCH}), 129.6(\mathrm{ArCH}), 131.6(\mathrm{ArC}), 144.7(\mathrm{C}), 151.6(\mathrm{C}), 171.4$ $(\mathrm{C}=\mathrm{O}), 175.0$ (C=O); IR (ATR): $v_{\max } 2905,2828,2725,2601,2533,1732,1650,1625,1431,1341,1211$, $1146,864,765,704,700 \mathrm{~cm}^{-1}$; UV (ACN): $\lambda_{\max } 276 \mathrm{~nm}\left(\varepsilon 13,011 \mathrm{~cm}^{-1} \mathrm{M}^{-1}\right)$; HRMS (ESI) $\mathrm{m} / z$ calcd for $\mathrm{C}_{13} \mathrm{H}_{11} \mathrm{NO}_{3} \mathrm{Na} 252.0631[\mathrm{M}+\mathrm{Na}]^{+}$, found 252.0632 .

Other derivatives (DHP acid 2-4) were synthesized by following the same method from the corresponding tert-butyl acetate DHPs.

\subsubsection{2-(5-Methylene-2-oxo-4-(2-fluorophenyl)-1,5-dihydro-2H-pyrrol-1-yl)acetic acid (DHP acid-2)}

M.p. $150{ }^{\circ} \mathrm{C} ;{ }^{1} \mathrm{H}-\mathrm{NMR}\left(400 \mathrm{MHz}, \mathrm{CDCl}_{3}\right) \delta 4.51\left(\mathrm{~s}, 2 \mathrm{H}, \mathrm{CH}_{2}\right), 4.94-4.97\left(\mathrm{~m}, 2 \mathrm{H},=\mathrm{CH}_{2}\right), 6.39(\mathrm{~s}, 1 \mathrm{H}$, $\mathrm{CH}), 7.16-7.24(\mathrm{~m}, 2 \mathrm{H}, \mathrm{ArH}), 7.35-7.45(\mathrm{~m}, 2 \mathrm{H}, \mathrm{ArH}) ;{ }^{13} \mathrm{C}-\mathrm{NMR}\left(100 \mathrm{MHz}, \mathrm{CDCl}_{3}\right) \delta 40.5\left(\mathrm{CH}_{2}\right), 97.1$ $\left(\mathrm{CH}_{2}\right), 116.2(\mathrm{CH}), 116.4(\mathrm{ArCH}), 123.5(\mathrm{ArC}), 124.2(\mathrm{ArCH}), 130.9(\mathrm{ArCH}), 131.3(\mathrm{ArCH}), 144.5(\mathrm{C})$, 145.0 (C), 161.0 (ArCF), 169.0 (C=O), 171.5 (C=O); IR (ATR): $v_{\max } 1549,2916,2603,2537,2104,1931$, $1727,1624,1486,1432,1352,1208,1085,882,832,759 \mathrm{~cm}^{-1}$; UV (ACN): $\lambda_{\max } 272 \mathrm{~nm}\left(\varepsilon 10,352 \mathrm{~cm}^{-1}\right.$ $\mathrm{M}^{-1}$ ); HRMS (ESI) $m / z$ calcd for $\mathrm{C}_{13} \mathrm{H}_{10} \mathrm{FNO}_{3} \mathrm{Na} 270.0537[\mathrm{M}+\mathrm{Na}]^{+}$, found 270.0535 .

\subsubsection{2-(5-Methylene-2-oxo-4-(4-fluorophenyl)-1,5-dihydro-2H-pyrrol-1-yl)acetic acid (DHP acid-3)}

M.p. $201-202{ }^{\circ} \mathrm{C} ;{ }^{1} \mathrm{H}-\mathrm{NMR}\left(400 \mathrm{MHz}, \mathrm{CDCl}_{3}\right) \delta 4.50\left(\mathrm{~s}, 2 \mathrm{H}, \mathrm{CH}_{2}\right), 4.96\left(\mathrm{t}, J=2.7 \mathrm{~Hz}, 1 \mathrm{H},=\mathrm{CH}_{2}\right)$, $5.01\left(\mathrm{~d}, J=2.7 \mathrm{~Hz}, 1 \mathrm{H},=\mathrm{CH}_{2}\right), 6.26(\mathrm{~s}, 1 \mathrm{H}, \mathrm{CH}), 7.13-7.17(\mathrm{~m}, 2 \mathrm{H}, \mathrm{ArH}), 7.41-7.44(\mathrm{~m}, 2 \mathrm{H}, \mathrm{ArH})$; ${ }^{13} \mathrm{C}-\mathrm{NMR}\left(100 \mathrm{MHz}, \mathrm{CDCl}_{3}\right) \delta 40.4\left(\mathrm{CH}_{2}\right), 97.2\left(\mathrm{CH}_{2}\right), 115.8(\mathrm{CH}), 116.1(2 \times \mathrm{ArCH}), 120.9(\mathrm{ArC}), 130.4$ $(2 \times \mathrm{ArCH}), 144.7(\mathrm{C}), 150.0(\mathrm{C}), 162.0(\mathrm{ArCF}), 168.9(\mathrm{C}=\mathrm{O}), 172.0(\mathrm{C}=\mathrm{O})$; IR (ATR): $v_{\max } 2886,2729$, 2606, 2538, 2116, 1733, 1655, 1628, 1501, 1430, 1351, 1212, 1144, 916, 882, 845, $770 \mathrm{~cm}^{-1}$; HRMS (ESI) $\mathrm{m} / \mathrm{z}$ calcd for $\mathrm{C}_{13} \mathrm{H}_{10} \mathrm{FNO}_{3} \mathrm{Na} 270.0537[\mathrm{M}+\mathrm{Na}]^{+}$, found 270.0534 .

4.2.5. 2-(5-Methylene-2-oxo-4-(4-bromophenyl)-1,5-dihydro-2H-pyrrol-1-yl)acetic acid (DHP acid-4)

M.p. $191{ }^{\circ} \mathrm{C} ;{ }^{1} \mathrm{H}-\mathrm{NMR}\left(300 \mathrm{MHz}\right.$, Acetone- $\left.\mathrm{d}_{6}\right) \delta 4.49\left(\mathrm{~s}, 2 \mathrm{H}, \mathrm{CH}_{2}\right), 4.04\left(\mathrm{~d}, J=2.4 \mathrm{~Hz}, 1 \mathrm{H},=\mathrm{CH}_{2}\right)$, $5.19\left(\mathrm{~s}, 1 \mathrm{H},=\mathrm{CH}_{2}\right), 6.4(\mathrm{~s}, 1 \mathrm{H}, \mathrm{CH}), 7.51(\mathrm{dd}, J=58.2$ and $8.4 \mathrm{~Hz}) ;{ }^{13} \mathrm{C}-\mathrm{NMR}\left(75.5 \mathrm{MHz}\right.$, Acetone- $\left.\mathrm{d}_{6}\right) \delta$ $40.0\left(\mathrm{CH}_{2}\right), 96.1\left(\mathrm{CH}_{2}\right), 121.3(\mathrm{CH}), 123.2(\mathrm{ArCBr}), 130.5(2 \times \mathrm{ArCH}), 131.5(\mathrm{C}), 132.0(2 \times \mathrm{ArCH}), 144.7$ (ArC), 149.3 (C), 167.9 (C=O), 168.7 (C=O); IR (ATR): $v_{\max } 3350,2918,2733,2528,2110,1908,1719,1664$, 1483, 1433, 1396, 1349, 1217, 1199, 1069, 873, $824 \mathrm{~cm}^{-1}$; UV (ACN): $\lambda_{\max } 222 \mathrm{~nm}\left(\varepsilon 10,897 \mathrm{~cm}^{-1} \mathrm{M}^{-1}\right)$, 278 (11,112); HRMS (ESI) $m / z$ calcd for $\mathrm{C}_{13} \mathrm{H}_{10} \mathrm{BrNO}_{3} \mathrm{Na} 329.9736[\mathrm{M}+\mathrm{Na}]^{+}$, found 329.9735. 


\subsection{6. (Z)-4-(1-Carboxy-3-oxobut-1-en-2-yl)benzoic acid 7}

Phosphoric acid $(15 \mathrm{~mL})$ was added to a solution of 4-(2-oxopropyl)benzoic acid ( $0.35 \mathrm{~g}, 1.5 \mathrm{mmol})$ and glyoxylic acid $(0.37 \mathrm{~g}, 4 \mathrm{mmol})$ and the mixture was heated at $75-80^{\circ} \mathrm{C}$ for $5 \mathrm{~h}$. The mixture was cooled to room temperature, extracted into 1:1 DCM/ether layer and dried over $\mathrm{MgSO}_{4}$. The solvent was evaporated under vacuum and purified by flash chromatography with 5:1 ethyl acetate/methanol to obtain a pale yellow solid $(0.18 \mathrm{~g}, 50 \%)$. M.p. $114-116{ }^{\circ} \mathrm{C} ;{ }^{1} \mathrm{H}-\mathrm{NMR}\left(300 \mathrm{MHz}, \mathrm{DMSO}-d_{6}\right) \delta 1.68$ (s, $\left.3 \mathrm{H}, \mathrm{CH}_{3}\right), \delta 6.8(\mathrm{~s}, 1 \mathrm{H},=\mathrm{CH}), \delta 8.0-8.05(\mathrm{~m}, 4 \mathrm{H}, \mathrm{ArH}), \delta 13.1$ (brs, $\left.1 \mathrm{H}, \mathrm{COOH}\right)$.

\subsubsection{5-Hydroxy-5-methyl-4-(4-carboxyphenyl)-1,5-dihydro-2H-pyrrol-2-one $\mathbf{1 0}$}

(Z)-4-(1-Carboxy-3-oxobut-1-en-2-yl)benzoic acid was treated with trifluoroacetic acid $(5 \mathrm{~mL})$ at room temperature for $1 \mathrm{~h}$. The solvent was removed under vacuum to yield a brown solid, presumably 5-hydroxy-5-methyl-4-(4-carboxyphenyl)-2(5H)furanone $(0.1 \mathrm{~g}, 0.42 \mathrm{mmol})$, which was dissolved in thionyl chloride $(5 \mathrm{~mL})$ and stirred at room temperature for $24 \mathrm{~h}$. The excess thionyl chloride was removed from the reaction mixture under high vacuum. The residue was stirred with ice-cold water for few minutes and then with aqueous ammonia $(7 \mathrm{~mL}, 30 \%)$ for $3 \mathrm{~h}$. The excess ammonia was removed in vacuo and the residue was acidified with $2 \mathrm{M} \mathrm{HCl}(3 \mathrm{~mL})$ to obtain a brown precipitate which was filtered under vacuum and subjected to flash chromatography with EtOAc/MeOH (9:1) to yield the title product as a white solid (0.035 g, 35\%). M.p. 198-200 ${ }^{\circ} \mathrm{C} ;{ }^{1} \mathrm{H}-\mathrm{NMR}\left(300 \mathrm{MHz}\right.$, DMSO- $\left.d_{6}\right) \delta 1.56$ (s, $\left.3 \mathrm{H}, \mathrm{CH}_{3}\right), 3.7(\mathrm{brs}, 1 \mathrm{H}, \mathrm{OH}), 6.7(\mathrm{~s}, 1 \mathrm{H}, \mathrm{CH}), 7.5(\mathrm{~s}, 1 \mathrm{H}, \mathrm{ArH}), 7.9(\mathrm{~m}, 3 \mathrm{H}, \mathrm{ArH}), 8.5(\mathrm{~s}, 1 \mathrm{H}, \mathrm{NH}), 13.0$ (brs, $1 \mathrm{H}, \mathrm{COOH}) ;{ }^{13} \mathrm{C}-\mathrm{NMR}\left(75.5 \mathrm{MHz}, \mathrm{DMSO}-d_{6}\right) \delta 26.7\left(\mathrm{CH}_{3}\right), 107.0(\mathrm{C}), 117.0(\mathrm{CH}), 128.9(2 \times \mathrm{ArCH})$, 130.2 (ArC), $130.5(2 \times \mathrm{ArCH}), 133.6(\mathrm{ArC}), 164.5(\mathrm{C}), 168.0(\mathrm{C}=\mathrm{O}), 170.0(\mathrm{C}=\mathrm{O})$; HRMS (ESI) $\mathrm{m} / z$ calcd for $\mathrm{C}_{12} \mathrm{H}_{11} \mathrm{NO}_{4} \mathrm{Na} 256.0580[\mathrm{M}+\mathrm{Na}]^{+}$, found 256.0580 .

\subsubsection{4-(4-Carboxy phenyl)-5-methyelene-1,5-dihydro-2H-pyrrol-2-one ( $p$-acid DHP) 11}

5-hydroxy-5-methyl-4-(4-carboxyphenyl)-1,5-dihydro-2H-pyrrol-2-one (0.2 g, $0.85 \mathrm{mmol})$ in borontrifluoride dietherate $(2 \mathrm{~mL})$ was stirred at room temperature for $24 \mathrm{~h}$. The resulting reaction mixture was filtered under vacuum, washed with cold water and dried. The residue was chromatographed on silica gel using EtOAc/MeOH (5:1) to yield the final product as a pale yellow solid (0.10 g, 50\%). M.p. $145-146{ }^{\circ} \mathrm{C} ;{ }^{1} \mathrm{H}-\mathrm{NMR}\left(300 \mathrm{MHz}\right.$, DMSO- $\left.d_{6}\right) \delta 4.91(\mathrm{~s}, 1 \mathrm{H}, \mathrm{CH}), 5.19\left(\mathrm{~s}, 1 \mathrm{H},=\mathrm{CH}_{2}\right), 6.42\left(\mathrm{~s}, 1 \mathrm{H},=\mathrm{CH}_{2}\right)$, 7.46-7.59 (m, 2H, ArH), 7.95-8.08 (m, 2H, ArH), $10.2(1 \mathrm{H}, \mathrm{COOH}) ;{ }^{13} \mathrm{C}-\mathrm{NMR}\left(75.5 \mathrm{MHz}, \mathrm{DMSO}-d_{6}\right) \delta$ $98.0\left(\mathrm{CH}_{2}\right), 123.7(\mathrm{CH}), 128.3(2 \times \mathrm{ArCH}), 128.8(2 \times \mathrm{ArCH}), 134.6(\mathrm{ArC}), 135.3(\mathrm{C}), 144.1(\mathrm{ArC}), 149.3(\mathrm{C})$, $167.7(\mathrm{C}=\mathrm{O}), 170.1$ (C=O); IR (ATR): $v_{\max } 3457,3361,3200,2358,2257,2109,1634,1600,1409,1189,1033$, 924, 848, 770, $741 \mathrm{~cm}^{-1}$; UV (THF): $\lambda_{\max } 236 \mathrm{~nm}\left(\varepsilon 8817 \mathrm{~cm}^{-1} \mathrm{M}^{-1}\right), 281$ (3935); HRMS (ESI) $\mathrm{m} / z$ calcd for $\mathrm{C}_{12} \mathrm{H}_{9} \mathrm{NO}_{3} \mathrm{H} 216.0655[\mathrm{M}+\mathrm{H}]^{+}$, found 216.0655 .

\subsection{Attachment of (3-Aminopropyl)triethoxysilane (APTES)}

Glass coverslips (No. 1, diameter 13 mm D 263 M glass, ProSciTech Pty Ltd, Kirwan Australia) were first cleaned in freshly prepared piranha solution (3:1 $\mathrm{v} / \mathrm{v}$ concentrated sulphuric acid to $30 \%$ hydrogen peroxide) at $100{ }^{\circ} \mathrm{C}$ for $1 \mathrm{~h}$. After thorough rinsing with distilled water, the clean coverslips were rinsed once with absolute ethanol and air-dried.

The coverslips were then silanized according to the previously developed method [26]. Briefly, the clean substrates were placed on a steel mesh within a glass vessel that contains a (3-aminopropyl)triethoxysilane (APTES) solution $(10 \% v / v$ in dry toluene; $1 \mathrm{~mL})$. The glass vessel was sealed and heated at $140{ }^{\circ} \mathrm{C}$ for $18 \mathrm{~h}$. The coverslips were rinsed with dry toluene $(\times 2)$, absolute ethanol and air-dried.

\subsection{Attachment of DHPS}

A solution containing DHP $(20.2 \mu \mathrm{M})$, EDC $(101.2 \mu \mathrm{M})$, NHS $(40.5 \mu \mathrm{M})$ and a small crystal of 4-dimethylaminopyridine (DMAP) in 1:1 ethanol/water was prepared. The amine-functionalized 
APTES glass surface was immersed in $1.5 \mathrm{~mL}$ of this solution and agitated overnight. The unreacted DHP was removed by extensively washing the samples with MilliQ water and absolute ethanol, and the surfaces were then air dried and stored in a clean sterile container.

\subsection{X-ray Photoelectron Spectroscopy}

X-ray photoelectron spectroscopy measurements were performed on an ESCALAB 220iXL Monochromatic Al K $\alpha$ X-rays (1486.6 eV) (ThermoFisher Scientific, North Ryde, Australia) incident at $58^{\circ}$ to the analyzer lens were used to excite electrons from the sample. Emitted photoelectrons were collected on a hemispherical analyzer with a multichannel detector at a take-off angle of $90^{\circ}$ from the plane of the sample surface. The analyzing chamber operated below 10-8 Torr, and the spot size was approximately $1 \mathrm{~mm}^{2}$. The resolution of the spectrometer was $\sim 0.6 \mathrm{eV}$. All energies are reported as binding energies in $\mathrm{eV}$ and referenced to the $\mathrm{C} 1 \mathrm{~s}$ signal (corrected to $285.0 \mathrm{eV}$ ). Survey scans were carried out at $100 \mathrm{~ms}$ dwell time and an analyzer pass energy of $100 \mathrm{eV}$. High-resolution scans were run with $0.1 \mathrm{eV}$ step size, dwell time of $100 \mathrm{~ms}$, and analyzer pass energy set to $20 \mathrm{eV}$. After background subtraction using the Shirley routine, spectra were fitted with a convolution of Lorentzian and Gaussian profiles as described by Ciampi et al. [47].

\subsection{Contact Angle Measurements}

Contact angles were determined using a contact angle goniometer (Rame-Hart, Inc, Succasunna, NJ, USA, Model no. 100-00). Multiple drops of deionized water were placed on each surface using a micro-syringe. The angle between the droplet and the surface was measured using a $50 \mathrm{~mm}$ Cosmicar Television Lens (Japan). Rame-Hart Imaging software (2002) was used to calculate the contact angle. A minimum of fifteen measurements were made on five samples.

\subsection{Bacterial Adhesion Analysis}

The bacterial strains used for this study, Staphylococcus aureus SA38 and Pseudomonas aeruginosa PA01, were streaked on chocolate agar (Oxoid, ThermoFisher Scientific, North Ryde, Australia) and incubated at $37^{\circ} \mathrm{C}$ overnight. A single colony of the bacteria from the pate was cultured overnight in $15 \mathrm{~mL}$ tryptone soya broth (TSB; Oxoid, ThermoFisher Scientific, North Ryde, Australia) medium at $37^{\circ} \mathrm{C}$. The bacteria were washed twice with the same volume of fresh TSB by centrifugation. The optical density of the resulting culture was adjusted to $\mathrm{OD}_{660}=0.1$ in TSB which corresponds to $1 \times 10^{8} \mathrm{cfu} \mathrm{mL}^{-1}$.

The surfaces to be tested were first sterilized with $70 \% \mathrm{w} / v$ ethanol for $30 \mathrm{~min}$ in a 12-well plate, then thoroughly washed with phosphate buffered saline (PBS) three times and finally placed in $4 \mathrm{~mL}$ of the above bacterial suspension. The plates were incubated at $37^{\circ} \mathrm{C}$, after $24 \mathrm{~h}$ the bacterial suspension was replaced with $4 \mathrm{~mL}$ of fresh TSB and incubated as before for the next $24 \mathrm{~h}$. The samples were gently washed twice with PBS to remove non-adherent bacteria before examining for bacterial adhesion by florescence microscopy.

Surfaces with adherent bacterial cells prepared as described above were stained with the Live/Dead BacLight Bacterial Viability Kit L-7007 (Molecular Probes Inc, Eugene, OR, USA) according to the manufacturers' procedure and as described in the literature for analysis of biofilms on surfaces $[22,26,48,49]$. Briefly, $2 \mu \mathrm{L}$ of the two components were mixed thoroughly in $1 \mathrm{~mL}$ of PBS; $100 \mu \mathrm{L}$ of the solution was then trapped between the sample and the glass microscopy slide and allowed to incubate at room temperature in the dark for $15 \mathrm{~min}$. Bacteria were then fixed by adding $100 \mu \mathrm{L}$ of $4 \%$ formaldehyde to each sample.

Microscopic observation and image acquisition were performed with an Olympus FV1200 Confocal Inverted Microscope (Olympus Australia Pty Ltd, Notting Hill, Australia). The bacterial cells that were stained green were considered to be viable, while those that stained red or both green and red were considered to be dead. Images from 10 representative areas on each of triplicate samples for each surface were taken and analyzed using ImageJ software [50]. The results were reported as the average percentage coverage of live and dead cells of the fields of view. 


\subsection{Statistical Analysis of Data}

For bacterial attachment assay further analysis of the was done by the one-way analysis of variance (ANOVA) using GraphPad Prism 7.03 software (GraphPad Software Inc, San Diego, CA, USA). Post hoc multiple comparisons were done using Tukey correction.

\subsection{Quorum Sensing Inhibition Assay}

To evaluate the effectiveness of the synthesized DHP derivatives against QS signaling, the P. aeruginosa MH602 $\mathrm{P}_{\text {las } B}:: g f p$ (ASV) reporter strain, which harbors a chromosomal fusion of the las $B$ promoter to an unstable gfp gene and which responds to the AHL 3-oxo-dodecanoyl homoserine lactone (3oxo-C12-HSL), was used [31]. To each well of the top row in a 96-well plate, $160 \mu \mathrm{L}$ of Luria-Bertani $\left(\mathrm{LB}_{10}\right)$ broth medium and $40 \mu \mathrm{L}$ of $5 \mathrm{mM}$ test compound in DMSO were added. The test compound was diluted by two-fold each time in $\mathrm{LB}_{10}$ broth medium in all subsequent wells. Then, $100 \mu \mathrm{L}$ of a 100-times diluted overnight culture of P. aeruginosa MH602 in $\mathrm{LB}_{10}$ broth was added to all wells, and the final volume in each well was $200 \mu \mathrm{L}$. The plates were incubated at $37^{\circ} \mathrm{C}$ for $15 \mathrm{~h}$ in a microplate reader (Wallac Victor, Perkin-Elmer, Melbourne, Australia), and every $30 \mathrm{~min}$ the plates were briefly shaken and measured for GFP expression (fluorescence: excitation $485 \mathrm{~nm}$, emission $535 \mathrm{~nm}$ ) and cell growth $\left(\mathrm{OD}_{600}\right)$. The inhibitory effect of a DMSO control (1\% of total volume) was examined in similar fashion but no inhibitory effect on either GFP expression or cell growth was observed.

\section{Conclusions}

In this study, the effect of molecular orientation of surface-immobilized DHPs on biological activity was evaluated by attaching different parts of the DHP to the surface using a specific attachment strategy. The $N$-substituted acid DHPs $1-4$ and the $p$-acid DHP were effective at reducing bacterial colonization of S. aureus and P. aeruginosa on glass surfaces. This study demonstrated the importance of the orientation of the DHP for S. aureus activity where the best activity occurred when the DHP was attached to the surface via $\mathrm{N}-1$ position of the lactam ring, exposing the pendant phenyl ring. While for P. aeruginosa activity, no difference was observed between the two attachment strategies. Future SAR studies on the antimicrobial activity of different substituents on the phenyl ring of attached DHPs will be carried out to further explore the difference in activity against Gram-positive and Gram-negative bacteria.

Author Contributions: Conceptualization, N.K. and K.H.; methodology, G.I., B.A., N.K., D.B. and M.W.; analysis, A.T. and R.C.; investigation, A.T. and K.H.; writing-original draft preparation, A.T., R.C. and N.K.; writing-review and editing, R.C., D.B., M.W. and N.K.; supervision, N.K and M.W.; funding acquisition, N.K. and M.W.

Funding: This work was supported by a Linkage Project from Australian Research Council grant (LP150100752). Aditi Taunk was supported by an Australian Postgraduate Award.

Acknowledgments: The authors would like to thank Bill Gong at the University of New South Wales Mark Wainwright Analytical Centre (UNSW MWAC) for the XPS measurements, and the Biomedical Imaging Facility at UNSW MWAC for assistance with the confocal laser scanning microscopy.

Conflicts of Interest: The authors declare no conflict of interest.

\section{References}

1. World Health Organization. The World Health Report 2000-Health Systems: Improving Performance; World Health Organization: Geneva, Switzerland, 2000.

2. Gatermann, S.; Funfstuck, R.; Handrick, W.; Leitritz, L.; Naber, K.; Podbielski, A.; Schmidt, H.; Sester, U.; Straube, E.; Wittke, J.W. MIQ 02: Urinary Tract Infections: Quality Standards for Microbiological Infections; Urban \& Fischer: München, Germany, 2005; pp. 8-21.

3. US Centers for Disease Control and Prevention. Antibiotic Resistance Threats in the United States; US Centers for Disease Control and Prevention: Atlanta, GA, USA, 2013. 
4. O'Neill, J. Tackling Drug-Resistant Infections Globally: Final Report and Recommendations. Review on Antimicrobial Resistance. 2016, pp. 1-40. Available online: https://amr-review.org/sites/default/files/160525_ Final\%20paper_with\%20cover.pdf (accessed on 20 June 2019).

5. O'Neill, J. Antimicrobial Resistance: Tackling a Crisis for the Health and Wealth of Nations. Review on Antimicrobial Resistance. 2014, pp. 1-16. Available online: https://amr-review.org/sites/default/files/AMR\% 20Review\%20Paper\%20-\%20Tackling\%20a\%20 crisis\%20for\%20the \%20health\%20and\%20wealth\%20 of \% 20nations_1.pdf (accessed on 20 June 2019).

6. Baddour, L.M.; Cha, Y.-M.; Wilson, W.R. Infections of Cardiovascular Implantable Electronic Devices. N. Engl. J. Med. 2012, 367, 842-849. [CrossRef] [PubMed]

7. Pye, A.D.; Lockhart, D.E.A.; Dawson, M.P.; Murray, C.A.; Smith, A.J. A review of dental implants and infection. J. Hosp. Infect. 2009, 72, 104-110. [CrossRef] [PubMed]

8. Saini, M.; Singh, Y.; Arora, P.; Arora, V.; Jain, K. Implant biomaterials: A comprehensive review. World J. Clin. Cases 2015, 3, 52. [CrossRef] [PubMed]

9. Ribeiro, M.; Monteiro, F.J.; Ferraz, M.P. Infection of orthopedic implants with emphasis on bacterial adhesion process and techniques used in studying bacterial-material interactions. Biomatter 2012, 2, 176-194. [CrossRef] [PubMed]

10. Ciorba, A.; Bovo, R.; Trevisi, P.; Rosignoli, M.; Aimoni, C.; Castiglione, A.; Martini, A. Postoperative complications in cochlear implants: A retrospective analysis of 438 consecutive cases. Eur. Arch. Otorhinolaryngol. 2012, 269, 1599-1603. [CrossRef] [PubMed]

11. Muench, P.J. Infections versus penile implants: The war on bugs. J. Urol. 2013, 189, 1631-1637. [CrossRef]

12. Mermel, L.A. Prevention of Instravascular Catheter-Related Infections. Ann. Intern. Med. 2000, 132, 391-402. [CrossRef] [PubMed]

13. Mermel, L.A. Correction: Catheter-Related Bloodstream Infections. Ann. Intern. Med. 2000, 133, 395.

14. Stickler, D.J. Susceptibility of antibiotic-resistant gram-negative bacteria to biocides: a perspective from the study of catheter biofilms. J. Appl. Microbiol. Symp. Suppl. 2002, 92, 163S-170S. [CrossRef]

15. Bainbridge, J.W.; Teimory, M.; Tabandeh, H.; Kirwan, J.F.; Dalton, R.; Reid, F.; Rostron, C.K. Intraocular lens implants and risk of endophthalmitis. Br. J. Ophthalmol. 1998, 82, 1312-1315. [CrossRef]

16. Hetrick, E.M.; Schoenfisch, M.H. Reducing implant-related infections: active release strategies. Chem. Soc. Rev. 2006, 35, 780. [CrossRef] [PubMed]

17. Lynch, A.S.; Robertson, G.T. Bacterial and fungal biofilm infections. Annu. Rev. Med. 2008, 59, 415-428. [CrossRef] [PubMed]

18. Busscher, H.J.; Van der Mei, H.C.; Subbiahdoss, G.; Jutte, P.C.; Van den Dungen, J.J.; Zaat, S.A.J.; Schultz, M.J.; Grainger, D.W. Biomaterial-Associated Infection: Locating the Finish Line in the Race for the Surface. Sci. Transl. Med. 2012, 4, 153rv10. [CrossRef] [PubMed]

19. Kumar, N.; Iskander, G. Furanone Compounds and Lactam Analogues Thereof. U.S. Patent No. 8,586,618, 19 November 2013.

20. Kumar, N.; Iskander, G. Novel Lactams 2007. WO 2007/085042 A1, 7 August 2014.

21. Ho, K.K.K.; Cole, N.; Chen, R.; Willcox, M.D.P.; Rice, S.A.; Kumar, N. Immobilization of antibacterial dihydropyrrol-2-ones on functional polymer supports to prevent bacterial infections in vivo. Antimicrob. Agents Chemother. 2012, 56, 1138-1141. [CrossRef] [PubMed]

22. Ho, K.K.K.; Chen, R.; Willcox, M.D.P.; Rice, S.A.; Cole, N.; Iskander, G.; Kumar, N. Quorum sensing inhibitory activities of surface immobilized antibacterial dihydropyrrolones via click chemistry. Biomaterials 2014, 35 , 2336-2345. [CrossRef] [PubMed]

23. Ozcelik, B.; Ka Kit Ho, K.; Glattauer, V.; Willcox, M.; Kumar, N.; Thissen, H. Poly(ethylene glycol)-Based Coatings Combining Low-Biofouling and Quorum-Sensing Inhibiting Properties to Reduce Bacterial Colonization. ACS Biomater. Sci. Eng. 2016, 3, 78-87. [CrossRef]

24. Taunk, A.; Ho, K.K.K.; Iskander, G.; Willcox, M.D.P.; Kumar, N. Surface immobilization of antibacterial quorum sensing inhibitors by photochemical activation. J. Biotechnol. Biomater. 2016, 6, 1000238. [CrossRef]

25. Almohaywi, B.; Yu, T.T.; Iskander, G.; Chan, D.S.H.; Ho, K.K.K.; Rice, S.; Black, D.S.C.; Griffith, R.; Kumar, N. Dihydropyrrolones as bacterial quorum sensing inhibitors. Bioorganic Med. Chem. Lett. 2019, 29, 1054-1059. [CrossRef] 
26. Ho, K.K.K.; Cole, N.; Chen, R.; Willcox, M.D.P.; Rice, S.A.; Kumar, N. Characterisation and in vitro activities of surface attached dihydropyrrol-2-ones against Gram-negative and Gram-positive bacteria. Biofouling 2010, 26, 913-921. [CrossRef]

27. Liu, X.; Feng, Q.; Bachhuka, A.; Vasilev, K. Surface modification by allylamine plasma polymerization promotes osteogenic differentiation of human adipose-derived stem cells. ACS Appl. Mater. Interfaces 2014, 6, 9733-9741. [CrossRef]

28. López-Pérez, P.M.; Marques, A.P.; Da Silva, R.M.P.; Pashkuleva, I.; Reis, R.L. Effect of chitosan membrane surface modification via plasma induced polymerization on the adhesion of osteoblast-like cells. J. Mater. Chem. 2007, 17, 4064-4071. [CrossRef]

29. Tenover, F.C. Development and spread of bacterial resistance to antimicrobial agents: an overview. Clin. Infect. Dis. 2001, 33, S108-S115. [CrossRef] [PubMed]

30. Clatworthy, A.E.; Pierson, E.; Hung, D.T. Targeting virulence: a new paradigm for antimicrobial therapy. Nat. Chem. Biol. 2007, 3, 541-548. [CrossRef] [PubMed]

31. Hentzer, M.; Riedel, K.; Rasmussen, T.B.; Heydorn, A.; Andersen, J.B.; Parsek, M.R.; Rice, S.A.; Eberl, L.; Molin, S.; Hoiby, N.; et al. Inhibition of quorum sensing in Pseudomonas aeruginosa biofilm bacteria by a halogenated furanone compound. Microbiology 2002, 148, 87-102. [CrossRef] [PubMed]

32. Flipo, M.; Desroses, M.; Lecat-Guillet, N.; Villemagne, B.; Blondiaux, N.; Leroux, F.; Piveteau, C.; Mathys, V.; Flament, M.P.; Siepmann, J.; et al. Ethionamide boosters. 2. Combining bioisosteric replacement and structure-based drug design to solve pharmacokinetic issues in a series of potent 1,2,4-oxadiazole EthR inhibitors. J. Med. Chem. 2012, 55, 68-83. [CrossRef]

33. Tsien, R.Y. The green fluorescent protein. Annu. Rev. Biochem. 1998, 67, 509-544. [CrossRef]

34. Phillips, G.J. Green fuorescent protein-A bright idea for the study of bacterial protein localization. FEMS Microbiol. Lett. 2001, 204, 9-18.

35. Hentzer, M.; Wu, H.; Andersen, J.B.; Riedel, K.; Rasmussen, T.B.; Bagge, N.; Kumar, N.; Schembri, M.A.; Song, Z.; Kristoffersen, P.; et al. Attenuation of Pseudomonas aeruginosa virulence by quorum sensing inhibitors. EMBO J. 2003, 22, 3803-3815. [CrossRef]

36. Strahl, H.; Hamoen, L.W. Membrane potential is important for bacterial cell division. Proc. Natl. Acad. Sci. USA 2010, 107, 12281-12286. [CrossRef]

37. Qazi, S.; Middleton, B.; Muharram, S.H.; Cockayne, A.; Hill, P.; O'Shea, P.; Chhabra, S.R.; Cámara, M.; Williams, $\mathrm{P}$. N-acylhomoserine lactones antagonize virulence gene expression and quorum sensing in Staphylococcus aureus. Infect. Immun. 2006, 74, 910-919. [CrossRef]

38. Donlan, R.M. Biofilms: Microbial life on surfaces. Emerg. Infect. Dis. 2002, 8, 881-890. [CrossRef] [PubMed]

39. Bruinsma, G.M.; Van der Mei, H.C.; Busscher, H.J. Bactetial adhesion to surface hydrophlic and hydrophobic contact lenses. Biomaterials 2001, 22, 3217-3224. [CrossRef]

40. Song, F.; Koo, H.; Ren, D. Effects of material properties on bacterial adhesion and biofilm formation. J. Dent. Res. 2015, 94, 1027-1034. [CrossRef] [PubMed]

41. Gomes, L.C.; Silva, L.N.; Simões, M.; Melo, L.F.; Mergulhão, F.J. Escherichia coli adhesion, biofilm development and antibiotic susceptibility on biomedical materials. J. Biomed. Mater. Res. Part A 2015, 103, 1414-1423. [CrossRef] [PubMed]

42. Guo, K.; Freguia, S.; Dennis, P.G.; Chen, X.; Donose, B.C.; Keller, J.; Gooding, J.J.; Rabaey, K. Effects of surface charge and hydrophobicity on anodic biofilm formation, community composition, and current generation in bioelectrochemical systems. Environ. Sci. Technol. 2013, 47, 7563-7570. [CrossRef] [PubMed]

43. Bendinger, B.; Rijnaarts, H.H.M.; Altendorf, K.; Zehnder, A.J.B. Physicochemical cell-surface and adhesive properties of coryneform bacteria related to the presence and chain-length of mycolic acids. Appl. Environ. Microbiol. 1993, 59, 3973-3977. [PubMed]

44. An, Y.H.; Friedman, R.J. Concise review of mechanisms of bacterial adhesion to biomaterial surfaces. J. Biomed. Mater. Res. 1998, 43, 338-348. [CrossRef]

45. Chen, R.; Willcox, M.D.P.; Cole, N.; Ho, K.K.K.; Rasul, R.; Denman, J.A.; Kumar, N. Characterization of chemoselective surface attachment of the cationic peptide melimine and its effects on antimicrobial activity. Acta Biomater. 2012, 8, 4371-4379. [CrossRef]

46. Taunk, A.; Chen, R.; Iskander, G.; Ho, K.K.K.; Black, D.S.C.; Willcox, M.D.P.; Kumar, N. Dual-Action Biomaterial Surfaces with Quorum Sensing Inhibitor and Nitric Oxide to Reduce Bacterial Colonization. ACS Biomater. Sci. Eng. 2018, 4, 4174-4182. [CrossRef] 
47. Ciampi, S.; Böcking, T.; Kilian, K.A.; James, M.; Harper, J.B.; Gooding, J.J. Functionalization of acetylene-terminated monolayers on $\mathrm{Si}(100)$ surfaces: A click chemistry approach. Langmuir 2007, 23, 9320-9329. [CrossRef]

48. Kirov, S.M.; Webb, J.S.; O’May, C.Y.; Reid, D.W.; Woo, J.K.K.; Rice, S.A.; Kjelleberg, S. Biofilm differentiation and dispersal in mucoid Pseudomonas aeruginosa isolates from patients with cystic fibrosis. Microbiology 2007, 153, 3264-3274. [CrossRef] [PubMed]

49. Barraud, N.; Hassett, D.J.; Hwang, S.-H.; Rice, S.A.; Kjelleberg, S.; Webb, J.S. Involvement of nitric oxide in biofilm dispersal of Pseudomonas aeruginosa. J. Bacteriol. 2006, 188, 7344-7353. [CrossRef] [PubMed]

50. Abràmoff, M.D.; Magalhães, P.J.; Ram, S.J. Image processing with imageJ. Biophotonics Int. 2004, 11, 36-41.

Sample Availability: Samples of the compounds are available from the authors.

(C) 2019 by the authors. Licensee MDPI, Basel, Switzerland. This article is an open access article distributed under the terms and conditions of the Creative Commons Attribution (CC BY) license (http://creativecommons.org/licenses/by/4.0/). 